\title{
Appraising Employment Accommodation Rights for Visually Impaired Teachers in Ethiopia: Overview of Selected Cities
}

\section{Abstract}

Shimeles Ashagre *

The stride of countries towards the implementation of international conceptions, standards and programmes is creating a fertile ground for persons with disability in their efforts to become part of the productive section of the population. Ethiopia's Proclamation No. 568/2008 embraces the social-constructionist model, a conception of disability that strives towards the reduction of hurdles on the participation of disabled persons. Ethiopia has also ratified the Convention on the Rights of Persons with Disability (CRPD) thereby endorsing accommodation in the employment rights of disabled persons. Arguably, Ethiopia did not go far enough in implementing the right of accommodation for visually impaired teachers in the high schools that are referred to in this comment, i.e., in Addis Ababa, Hawassa, Soddo and Arba Minch. This is attributable to the level of awareness of the employers about this right and the lack of finance to install some technological apparatus in this respect. Ethiopia should thus work hard to realize its commitment in the Convention by addressing the needs of Ethiopian teachers with visual impairment.

\section{Key words}

Disability, visually impaired, medical model, quota model, social model, discrimination, Ethiopia

DOI http://dx.doi.org/10.4314/mlr.v8i2.5

\section{Introduction}

The Proclamation on the Right to Employment of Persons with Disability provides for reasonable accommodation as an important tool for the

\footnotetext{
* Lecturer of law, Hawassa University Law School; LL.B 2004, LL.M 2009, Addis Ababa University.
} 
realization of equal opportunity. This comment evaluates the implementation of reasonable accommodation, highlights the justification for the introduction of this scheme and it discusses the failure of employers to accommodate persons with disabilities.

The first section forwards a brief theoretical framework on the social constructionist model in the disability discourse. Section 2 discusses the state of anti-discrimination laws in Ethiopia (the Constitution, Proclamation 110/1994 and Proclamation 568/2008) in light of the various conceptual frameworks that have influenced these laws. The third section dwells on the justifications for the adoption of reasonable accommodation in lieu of the quota system. The level of implementation of reasonable accommodation is also evaluated since the law is in force. The last section forwards comments on the enforcement of reasonable accommodation and the challenges thereof based on 300 questionnaires administered on visually impaired teachers. The conclusion reflects on possible obstacles in the course of implementing reasonable accommodation.

\section{The Shift from the Medical Model to the Social- Constructionist Model}

At present, the government of Ethiopia has changed the perception of disability from the 'medical model' to the 'social model.' Proclamation, No $101 / 1994^{1}$ labeled a person disabled where he "is unable to see, hear or speak" if one suffers "from injuries to his limbs or from mental retardation, due to natural or man-made causes." In line with the legislation, the National Program of Action defined disability as "any restriction or lack (resulting from any loss or abnormality of psychological, physiological, or anatomical structure of function) of ability to perform an activity in the manner or within the range considered normal for a human being."

The Proclamation and the National Program of Action located disability in the medical model that depicts individuals with disability as "suffering subjects, characterized by the devastating changes and crises for both themselves and their families". 2 The medical model "holds a person's

${ }^{1}$ The Right to Employment of Persons with disability Proclamation No. 101/ 1994, Art. $2(1)$.

2 Hartman, Macintosh, \& Engelhardt (1983), 'The neglected and forgotten sexual partner of the physically disabled,' J. Social Work, vol. 28, pp. 370-374. 
physical or mental impairments responsible for disadvantages associated with disabilities". 3

Principally, the medical model relies on "rehabilitation and welfare facilities to mediate or accommodate the effects of disability by establishing separate facilities, such as nursing homes, sheltered workshops, and special education schools". The establishment of separate facilities is based on the assumption that "the needs for people with disability are better served in separate facilities that can be constructed to meet very specialized needs". 5 These facilities, needless to say, are "characterized as charitable efforts to respond to their neediness". 6

With the purpose of shifting the understanding of disability in the laws of Ethiopia, the Ethiopian parliament endorsed a new disability employment proclamation. ${ }^{7}$ The need for the change of the understanding of disability is discernible through paragraph 1 of the Preamble of the Proclamation that reads: "the negative perception of persons' disablement in society is deep rooted that, it has adversely affected the right of persons with disability to employment." This proclamation has endorsed the social-constructionist model as envisaged under Art. 2(1). It aims at: "physical, mental, or sensory impairments in relation with social, economic and cultural discrimination." As, Ato Kassahun Yibeltal, the former President of the Ethiopian Federation of the Associations of Persons with Disability, notes:

There was a lengthy discussion among the members of the technical committee which was composed of members delegated by the Civil Service Agency, the Ministry of Labor and Social Affairs and our Federation which model to adopt, that is, the Charity, the medical, or the social-constructionist model of disability. Of course, we have finally

\footnotetext{
${ }^{3}$ Katharina Heyer (2007), A Disability Lens on Sociolegal Research: Reading Rights of Inclusion from a Disability Studies Perspective,' Law \& Social Inquiry Vol. 32 No. 1, pp. 261-293.

${ }^{4}$ Lisa Wadington (1996), 'Legislating to Employ People with Disability: The European and the American Way' Maastricht Journal of European and Comparative Law, vol. $1,367-95$.

${ }^{5}$ Heyer supra note. 3, pp. 261-293.

${ }^{6}$ See, e.g., Paula E. Berg (1999), 'Ill/Legal: Interrogating the Meaning and Function of the Category of Disability in Antidiscrimination Law,' Yale L. Y Pol'y Rev. Vol. No. 18 1; Samuel R. Bagenstos, 'Subordination, Stigma, and-Disability,' VA. L. Rev.. Vol. 86 (2000 p. 397); Mary Crossley (1999), 'the Disability Kaleidoscope', Notre Dame L. Rev. Vol. 74, p. 621).

7 The Right to Employment of Persons with Disability Proclamation, 2008, Proc. No. 568, Fed. Neg. Gaz., Year 14, No. 20).
} 
come to truce on the entrenchment of the social/human rights model in to the Proclamation. ${ }^{8}$

The social-constructionist model claims that "disability is a social construction and not the inevitable result of personal injury or illness". 9 This model stems from the belief that "all non-social conceptions, or "medical models' of disability are fatally flawed". ${ }^{10}$ In opposition to the medical model, "the social model explains the disadvantages as a product of negative attitudes and systemic discrimination that result in system-wide barriers to information, communication, and the physical environment". ${ }^{11}$ Hence, the proponents of this model underline that conversant to the medical model "the social model would do away with the parallel track and focus on ways to make social environments accessible and reform social institutions to include people with disabilities [with the] assumption that once the nondisabled majority gains increasing contact with their disabled peers, discriminatory attitudes and fears of the unknown 'other' will disappear". ${ }^{12}$ Phillip Cole, in this respect, writes:

"The social model identifies a framework of empowerment, liberation and participation, and in that framework the ideas of disability and bodily impairment take on a distinct meaning." "13 Generally speaking, "[m]any of the barriers that people with disabilities face are the consequences of having those physical impairments under existing social and economic arrangements, especially the means of industrial production ... [that] do not accommodate the physical conditions or integrate the struggles of peoples with disabilities into the cultural concept of everyday life". ${ }^{14}$

The discussions so far made illuminate the fact that disability arises from "all [of the] factors that impose restrictions on people with disability,

8 Interview with Ato Kassahun Yibeltal, the former President of the Ethiopian Federation of the Associations of Persons with Disability, 23 Tir 2001 as quoted in Shimeles Ashagre, 2009.

${ }^{9}$ Heyer, supra at note 3 .

${ }^{10}$ John Harris, 'Is there a coherent social conception of disability?' Journal of Medical Ethics, Vol. 26 (2000) pp. 95-100, p. 95.

${ }^{11}$ Heyer, supra at note 3 .

${ }^{12}$ Ibid.

${ }^{13}$ Phillip Cole, 'The Body Politic: Theorising Disability and Impairment,' Journal of Applied Philosophy, Vol. 24 No. 2 (2007), pp. 169-176.

${ }^{14}$ Shimeles Ashagre (2009), The Enforcement of the Employment Rights of Persons with Disabilities in Ethiopia, (unpublished masters thesis), Archives of the Addis Ababa University, p. 8 (hereinafter, Shimeles). 
ranging from negative social attitudes to institutional discrimination, from inaccessible public buildings to unusable transport systems, from segregated education to exclusion in work arrangements, and so on". ${ }^{15}$ In sum, the failure of these social and economic systems "to accommodate the physical conditions or to integrate the struggles of peoples with disability into the everyday life" ${ }^{" 16}$ has resulted in considerable negative repercussions.

\section{The State of the Anti-discrimination Laws in Ethiopia}

Ten per cent of Ethiopia's population lives with some sort of impairment. ${ }^{17}$ Proclamation No. 101/1994 provided for the equal opportunity of employment for disabled persons. This proclamation reflected the view of various disability scholars who strenuously oppose the 'people first' movement that was principally put forward by other disability scholars. The Proclamation with its principal objective of establishing the quota system did not bring about a meaningful change in the life of people with disabilities in the country, and it is replaced by Proc. No. 568/2008. The new proclamation endorses the 'people first' motto, and it has changed the philosophical basis of disability in Ethiopia: from the medical model to the social model or, as is presently called, the human rights model.

\subsection{The Federal Constitution}

As Frankenberg observes, "constitution-like nation, state, democracy, and sovereignty - is one of the central icons and one of the most ambivalent ideological structures in the pool of cultural representations of modernity". ${ }^{18}$ The systematic ranking of constitutional norms at the top of the legal hierarchy, the methodological rule that laws have to be interpreted in conformity with the constitution and the language of the document characterizing its substantive content as consisting of inalienable sacred and natural rights or 'humble obligations' and 'lofty duties' ${ }^{19}$ ascertain the pedestal position constitutions occupy in any legal system. In this accord,

${ }^{15}$ Oliver, M., (1990), The politics of disablement: A sociological approach (Palgrave Macmillan), p. 32.

${ }^{16}$ Shimeles, supra at note 14, p. 8.

${ }^{17}$ Institute of Educational Research, Baseline Survey on Disabilities in Ethiopia (Addis Ababa University, 1995) as quoted in ILO, Employment of People with Disabilities: The Impact of Legislation (East Africa) (ILO, Geneva, March 2004), p. 3, (hereinafter, Baseline Survey on Disabilities in Ethiopia).

${ }^{18}$ Günter Frankenberg (2007), 'Comparing Constitutions: Ideas, ideals, and ideologytoward a layered narrative,' Int. Jnl. of Constitutional Law, Vol. 4, No. 3, note 33.

${ }^{19}$ Ibid. 
Art. 9 (1) of the Constitution of the Federal Democratic Republic of Ethiopia (hereinafter the Federal Constitution), superimposes the document 'on any law, customary practice, or a decision of an organ of a state or a public official' and prohibits any form of discrimination under Art. $25{ }^{20}$ However, this provision fails to give an explicit prohibition of discrimination against persons with disability. Here, it may be argued that the failure of the Constitution to explicitly prohibit any form of discrimination against persons with disabilities while forbidding any form of discrimination on grounds of race, nation, nationality, or other social origin, colour, sex, language, religion, political or other opinion, property, birth, needs to be rectified.

Conversely, it is possible to argue that the catch-all phrase 'other status' comprises the clearly unmentioned grounds including disabled persons. It is not, however, completely clear what other grounds are covered by the term 'other status'. According to Thornberry, unmentioned grounds must logically be "materially similar with those listed, [i.e.,] distinctions unrelated to an individual's merit, abilities or efforts". ${ }^{21}$ Adopting such a definition may not serve our purpose because there is no such word that denotes the necessity of the existence of material similarity. Therefore, it would be safer to adopt the observation of Scheinin and Krause, who note that "many grounds explicitly mentioned relate to inborn characteristics or other factors beyond the free choice of the affected person, which may be relevant in the interpretation of what constitutes "other status'.",2 In this context, it is undeniable that disability can be inborn or may occur after birth; it is, however, necessary to note that it is beyond the free choice of the individual with the disability. The quandary, however, is that "differentiation on grounds not explicitly mentioned (such as disability) is likely to be tested less strictly (i.e. such differentiation is more readily accepted as legitimate)

${ }^{20}$ The Federal Constitution of Ethiopia, 1995, Proc. No. 1, Fed. Neg. Gaz., Year 1, No. 1 (hereinafter the Constitution): All persons are equal before the law and are entitled without any discrimination to the equal protection of the law. In this respect, the law shall guarantee to all persons equal and effective protection without discrimination on grounds of race, nation, nationality, or other social origin, colour, sex, language, religion, political or other opinion, property, birth or other status.

${ }^{21}$ Patric Thornberry (1991), International Law and the Rights of Minorities, (Oxford: Oxford University Press), p. 281.

${ }^{22}$ Scheinin \& Krause (2000), The Right not to be discriminated Against: The Case of Social Security, Orlin \& Scheinin, p. 256. 
than differentiation on grounds that are explicitly mentioned, even if they are regarded as belonging to the 'other status' category". ${ }^{23}$

The other observable point, at this juncture, is that the catch-all phrase 'other status' should be interpreted narrowly; that is, the phrase should only apply to grounds that were not in existence at the time. In this vein, it is obvious that there existed discrimination on grounds of disability. So the application of the phrase to disabled persons is unconvincing. Therefore, it is the opinion of the author that the Constitution should be amended to include disability as one of the grounds against discrimination.

Meanwhile, the Constitution, in the section that provides for the protection of socio-economic rights, ${ }^{24}$ requires the State to "within its available means, allocate resources to provide rehabilitation and assistance to the physically and mentally disabled, the aged, and to children who are left without parents or guardian". ${ }^{25}$ This provision is suggestive of the adoption of the medical model of disability that demands for a specialized and segregated system of institutionalization for disabled peoples. Above all, the grouping of disabled persons with the aged and children, "who are clearly unproductive" 26 has hugely impacted the employability of disabled persons. This argument transpires from the query that "why would productive people contract to cooperate with unproductive individuals whose inclusion in the cooperative scheme brings no additional resources to the common store?"27 The stance of the Constitution, it may be argued, seems to maintain the status quo. In this vein, Patricia Smith ${ }^{28}$ contends that:

Indeed, one primary purpose of law is to promote stability and order by reinforcing adherence to predominant norms, representing them not only as the official values of a society ("our fundamental commitments" or "our way of life"), but often as universal, natural, and inevitable. Law sets the standard for what is normal and accepted. The law states the official position on matters that are required, prohibited, protected, or allowed.

${ }^{23}$ Irene P. Asscher-Vonk (1999), Towards One Concept of Objective Justification, in Loenen \& Rodrigues (Eds.), Non- Discrimination Law: Comparative Perspectives, Kluwer Law International, The Hague, p. 50

${ }^{24}$ The Constitution, Art. 41.

${ }^{25}$ Id., Art. 41 (5).

${ }^{26}$ Shimeles, supra at note 14, p. 82.

${ }^{27}$ Anita Silvers \& Michael Ashley Stein (2007), 'Disability and the Social Contract,' the University of Chicago Law Review, Vol. 74, pp. 1615-1640, p. 1615.

28 Patricia Smith (2009), 'Feminist Philosophy of Law,' Stanford Encyclopedia of Philosophy, Tue May 19, accessed in October 24, 2011. 
More importantly, "Article 42 of the Constitution whose concern is labor related rights does not even mention the right of persons with disability to equal employment opportunities". ${ }^{29}$

\subsection{Proclamation No. 101/1994}

Paragraph 2 of the preamble of Proclamation No. 101/1994 stated that "disabled persons have got less job opportunities, despite the fact that some of them have acquired the appropriate training and skills." The Baseline Study conducted by the Institute of Educational Research confirms this statement. It reads " 60 per cent of persons with disability in Ethiopia were unemployed in 1995, of which two-thirds were self-employed in rural areas in occupations such as agriculture, animal husbandry or forest activities". ${ }^{30}$

Article 3(1) of the Proclamation stated the need to give an end to the disheartening unemployment level of disabled persons and stated that, "disabled persons with the necessary qualifications can, unless the nature of the work dictates ... otherwise, compete and be selected for vacant posts, promotion and training programs" $" 31$ [italics added]. However, no provision in the Proclamation defined the phrase "necessary qualifications". Hence, employers may put any criteria they feel will debar a disabled person from employment, and no guidelines are provided for employers in the evaluation of the qualification of that person. Moreover, the phrase "unless the nature of the work dictates ... otherwise", lacked a clear-cut definition. Employers could thus use this silence as an excuse to differential treatment against persons with disability during recruitment, promotion, transfer and selection for training programs.

According to Art. 3(4) of this Proclamation, an employer has to provide disabled employees with the necessary equipment and materials in order to enable them to carry out their duties or pursue training. Essentially, the Proclamation presupposes that employers should reasonably accommodate disabled persons. Admittedly, such a requirement places additional economic burden on the employer and this may have a negative impact on candidates with disability. The proclamation does not, however, provide for the possible ways by which the burdens on the employers could be shared by the government.

Beyond reasonable accommodation, Art. 4(1)-(2) of the Proclamation required "employers and training institutions ... to identify and reserve posts

\footnotetext{
${ }^{29}$ Shimeles, supra at note 14 , p. 39.

${ }^{30}$ Baseline Survey on Disabilities in Ethiopia, supra at note 17, p. 3.

${ }^{31}$ The Right to Employment for Disabled Persons Proclamation, supra note 1, Art. 3(1).
} 
for persons with disability from among vacancies, to be competed only by persons with disability." The reservation of posts is, by definition, a "positive action, which allows for special help to [disabled persons] on the grounds of their disadvantaged situation in getting and retaining employment" ${ }^{32}$ The underlying assumptions of such reservations are:

a) people with disability are able to work in the open labor market;

b) employers should hire a set percentage of people with a disability; and

c) a large number of people with disability are neither able to compete for jobs with their non-disabled counterparts on an equal basis nor win jobs on their own merit, thus rendering legislative intervention necessary. ${ }^{33}$

Wadington notes the following paradox in the reservation of posts:

On the one hand, employers are told that persons with disability' employment in the open labor market is desirable and achievable, whilst on the other hand; they are told that workers with disability cannot compete for jobs in a truly open labor market. In short, the message sent out is that most workers with disability are less valuable economically and less productive, and that, if such workers are to be integrated in the (semi-) open labor market, employers need to be obliged to hire them. ${ }^{34}$

However, the tide is swinging away from quotas. It is either being abandoned altogether (as in the UK), or other measures such as "active employment support for individuals and/or stronger anti-discrimination laws" are being "given higher profile and greater force". ${ }^{35}$ Ethiopia has abandoned the quota since Proclamation No. 101.1994 was repealed by Proclamation No. 568/2008. During its years of operation, this scheme was without any progress; and no guidelines were issued. Nor were employers required to develop there own mechanism of judgment.

\subsection{Proclamation No. 568/2008}

This proclamation was drafted with the aim of replacing the earlier legislation on the right of persons with disability to employment which had,

\footnotetext{
${ }^{32}$ Daniel Mont, 'Disability Employment Policy,' (2004), http://siteresources.worldbank.org/DISABILITY/Resources/2806581172606503948/DisabilityEmploymentMont.pdf.

${ }^{33}$ Wadington, supra at note 4.

${ }^{34}$ Ibid.

${ }^{35}$ Mont, supra at note 32.
} 
"by providing for reservations of vacancies for persons with disability, created an image in the mind of the employers that people with disability were incapable of performing jobs based on merit". "Proclamation No. $568 / 2008$ (hereinafter 'the proclamation') seeks to downsize "the deep rooted negative perception of persons' disablement in society that has adversely affected the right of persons with disability to employment". ${ }^{37}$ The Proclamation was enacted with the purpose of "guarantee[ing] the right of persons with disability to reasonable accommodation and the provision of proper protection" ${ }^{38}$ from the prevalent discriminatory practices. This law is expected to enable Ethiopia to comply with the "policy of equal employment opportunity, provision of reasonable accommodation for people with disability to employment and laying down simple procedural rule that enable them to prove before any judicial organ discriminations encountered in employment". ${ }^{39}$

One can note the following departures of the Proclamation from previous laws. The Proclamation has departed from its predecessor by guaranteeing the "right of action" in cases of employment discrimination that occurs against persons with disability. Under such circumstances, the association of persons with disabilities, the individual or the trade union which he is a member is entitled to file a suit at courts. ${ }^{40}$

Art. 6(2) of the former proclamation, i.e. Proclamation No. 101/1994, had guaranteed this right of suit only to the individual who suffered from the discrimination. Article 11 of Proclamation No. 568/2008 has filled the gap on the enforcement of the rights of persons with disability, and it imposes a sanction against violation in the form of a fee not less than two thousand or more than five thousand Birr. This takes the latter a step ahead from the previous proclamation. Moreover, while Article 5 of Proclamation No. $568 / 2008$ clearly provides for the prohibition of possible discrimination that can occur on persons with disability, in situations of recruitment and promotion by virtue of, the former had provided for a quota.

Another major departure of the Proclamation from its predecessor relates to the adoption of reverse burden of proof. The Proclamation requires the defendant to prove the non-existence of the discrimination ${ }^{41}$ or the defendant

\footnotetext{
${ }^{36}$ Preamble Para. 2.

${ }^{37}$ Id. Para. 1.

${ }^{38}$ Id. Para. 3.

${ }^{39}$ Ibid.

${ }^{40}$ Id., Art. 10 (1).

${ }^{41}$ Id., Art. 7 (2).
} 
is required to prove that the work cannot be handled by a qualified person with disability even if reasonable accommodation is in place. The Proclamation has also introduced the defense of "undue burden", which can be invoked by employers as highlighted in the next section.

\section{The Principles of Reasonable Accommodation and Sanctions against Violation}

It is nearly 40 years since ILO's supervisory and policy-making bodies endorsed the desirability of safeguarding disabled persons from discrimination on the assumption that "persons whose capacity is reduced by physical or mental disability often encounter discrimination even in respect of jobs which their disability would not prevent them from discharging efficiently and that persons with disability need special help in order to enjoy equality of opportunity in employment that is adapted to their particular condition". ${ }^{42}$ Similarly, the Committee on Economic, Social and Cultural Rights, has underlined that "the obligation in the case of such a vulnerable and disadvantaged group is to take positive action to reduce structural disadvantages and to give appropriate preferential treatment in order to achieve the objectives of full participation and equality within society for all persons with disability". ${ }^{43}$

These actions "are not to be considered discriminatory as long as they are based on the principle of equality and are employed only to the extent necessary to achieve that objective". ${ }^{44}$ Positive action or other preferential measures are allowed and may even be required, if they are needed to correct discrimination and are used only as long as is necessary. In this relation, Hugh Collins, states three deviations from "equal treatment" that are "justified by reference to the pursuit of goals such as equality of results, equality of resources, or equality of opportunity" ${ }^{45} \mathrm{He}$ notes:

First, in some cases, different rather than the same treatment is required.

[For instance], different treatment of persons with disability is required

${ }^{42}$ General Survey on the Vocational Rehabilitation and Employment (Disabled Persons) Convention (No. 159) and Recommendation (No. 168), 1983, Geneva, June 1998, http://wallis.kezenfogva.iif.hu/eu_konyvtar/projektek/vocational_rehabilitiation/publ/ gen_31.htm.

43 General Comment No. 5, Persons with disabilities, 1994, adopted at the Eleventh session of the UN Committee on Economic, Social and Cultural Rights, Para. 9.

${ }^{44}$ Id., Para 18.

${ }^{45}$ Hugh Collins, 'Discrimination, Equality and Social Inclusion,' Modern Law Review, 66 (1) 
in many respects, in order to enable them to gain access to work and other opportunities. Secondly, equal treatment is itself not permitted, if it causes unjustifiable 'indirect discrimination' or 'disparate impact'. Meaning, equal treatment becomes unlawful where a rule or practice disproportionately operates to the disadvantage of one of the protected groups, and the rule or practice cannot be objectively justified. A third kind of deviation permits preferential treatment for protected groups in certain circumstances, in order to redress a prior history of disadvantage. ${ }^{46}$

More specifically, Anita Silvers reflects upon differential treatment for disabled persons from the perspectives of the following two points:

The first point is that, in some instances, equal treatment of people with disabilities requires an individual disabled person to be treated differently from, rather than identically to, a non-disabled peer. The second point is that accommodations, when understood as steps to remove discriminatory and exclusionary barriers to disabled persons' participation in society, are properly seen as instruments of equality for people with disabilities, rather than as special benefits. ${ }^{47}$

Essentially, the need for differential treatment is indicated under the previous paragraphs with regard to the realization of equal treatment of employees with disability. As a matter of fact, the "absence of a reasonable accommodation that would result in the inability of the equal opportunity of the disabled person is a discriminatory act". ${ }^{48}$ In other words, reasonable accommodation is taken as a mechanism of guaranteeing the right to a differential treatment.

One of the obligations under the Convention on the Rights of Persons with Disabilities (CRPD, as envisaged under Art. 27 (1)(I), is to "ensure that reasonable accommodation is provided to persons with disability in the workplace." Indeed, an anti-discrimination legislation that embraces the concept of reasonable accommodation draws on the idea that some adjustments in the workplace are necessary in order to place people with disability on an equal footing. In other words, reasonable accommodation is "necessary to allow a person with a disability an opportunity equal to that

\footnotetext{
${ }^{46}$ Ibid.

${ }^{47}$ Anita Silvers, Formal Justice, in Anita Silvers, David Wasserman \& may Mahowald (1998), Disability, Difference, Discrimination: Perspectives on Justice in Bioethics and Public Policy, 127.

48 The Proclamation, supra at note 24, Art. 5 (3).
} 
enjoyed by her non-disabled peers to demonstrate her job-related capabilities". ${ }^{49}$ For example, the accommodations, according to the Americans with Disabilities Act (ADA) can take the form of '(a) qualified interpreters or other effective methods of making aurally delivered materials available to individuals with hearing impairments; (b) qualified readers, taped texts, or other effective methods of making visually delivered materials available to individuals with visual impairments; and (c) acquisition or modification of equipment or devices'. ${ }^{50}$

Equality cannot be effectively applied to persons with disability without first adjusting the conditions of their situation as judged against that of other workers. That is why the obstacles intrinsic in the environment of work that are not adapted to the needs of people with disability ought to be removed. Or else, persons with disability stumble upon hurdles that are unpremeditated but that discriminate against them. Justice McIntyre J., in this regard, stated:

An employment rule honestly made for sound economic and business reasons and equally applicable to all to whom it is intended to apply, may nevertheless be discriminatory if it affects a person or persons differently from others to whom it is intended to apply. The intent to discriminate is not a governing factor in construing human rights legislation aimed at eliminating discrimination. Rather, it is the result or effect of the alleged discriminatory action that is significant. ${ }^{51}$

Hence, the incidence of premeditated or unpremeditated discrimination coerces the employer to "adjust the work environment, job requirement, and job function in order to give a chance for the qualified disabled individual to take equal benefits and privileges of employment"52 "short of undue hardship in the operation of the employer's business". ${ }^{53}$ The actions for the accommodation may vary. For example, the employer may purchase specially designed ergonomic equipment, modify a work schedule, invest in voice recognition software, or shift some nonessential functions of a particular job to another employee. Therefore, an employer who enables a blind employee to use a computer can eliminate employment barriers for

49 Arlene B. Mayerson \& Silvia Yee (2001), 'The ADA and Models of Equality,' OHIO ST. L.J. Vol. 62, 535, p. 542.

${ }^{50}$ The American with Disabilities Act, 1990, Sec. 3 (1).

${ }^{51}$ Mont, supra at note 32.

${ }^{52}$ Yvonne Peters, 'Twenty Years of Litigating for Disability Equality Rights: Has it Made a Difference?' 2004 http://www.ccdonline.ca/publications/20yrs/20yrs.htm

${ }^{53}$ Mont, supra at note 32. 
that person by installing speech reader software on the computer, thereby accommodating that employees need to access print information.

Nonetheless, employers would not be required to provide accommodations where they could prove that it would cause an undue hardship. Wilson noted that "financial cost, disruption of a collective agreement, problems of morale of other employees, interchangeability of work force and facilities" "54 may form some of the factors that create undue hardship on the employer.

In a comparatively similar fashion, the Article 2(6) of the Proclamation defines undue burden as" an action that entails considerable difficulty or expense on the employer in accommodating persons with disability when considered in light of the nature and cost of adjustments, the size and structure of the business, the cost of its operations, and the number and composition of its employees". 55 In this case, an employer may avoid the responsibility in either of the following two cases using the defense of "undue burden". The responsibilities of an employer which can be relieved in the event of undue burden are the duties stated in Articles 6(1)(a) and 6(1)(b) of the Proclamation which stipulate the duties to

a) take measures to provide appropriate working and training conditions and working and training materials for persons with disability;

b) take all reasonable accommodation and measures of affirmative action to women with disability taking into account their multiple burden.

While Article 6(2) relieves the employer from the preceding two responsibilities in the event of undue burden, this provision does not allow defense of undue burden for an employer's failure of assigning of an assistant for a person with a disability.

Employers can also escape the duty to accommodate by arguing that the discriminatory action protested of was a bona fide occupational requirement or qualification which alludes to "a standard that has been demonstrated to be rationally connected to the business in question, has been imposed in good faith, and is reasonably necessary to carry out the objectives of the business". ${ }^{56}$ Moreover, employers can also make use of the defense based on the nature of the job. To this effect, the Proclamation relieves employers from any blame where they exclude disabled persons from competitions for

\footnotetext{
${ }^{54}$ Ibid.

${ }^{55}$ Art. 2 (6).

${ }^{56}$ Peters, supra at note 52.
} 
"a job that could not be performed by a qualified person with disability even if reasonable accommodation is provided" ${ }^{57}$ For instance, it is clear from the outset that no visually impaired persons can compete for a job of a pilot.

Generally, an employer is obligated to "take measures to provide appropriate working conditions [and] materials for persons with disability" ${ }^{58}$ Even though the Proclamation incorporates the necessity of providing appropriate working conditions and materials, it fails to state which materials are appropriate for the proper completion of the work and the conditions thereof.

One of the improvements of the present Proclamation from its predecessor is that the present Proclamation has widened the scope of opportunities to file suits by potential victims of discrimination against an employer who has infringed the right of a person with disability. Article 10 provides:

Any person with disability whose rights are infringed due to nonobservance of the provisions of this Proclamation, Regulations or Directives issued for the proper implementation of this Proclamation or the association of persons with disability of which he is a member, or the trade union of which he is a member, or the concerned organ entrusted to implement this Proclamation may institute a suit before a competent court.

The person discriminated against can institute the case in "the Federal First Instance Court or regional High Court or federal or regional civil service administrative tribunal." Secondly, the association he is a member to can intervene in the issue and institute the case against the employer. More importantly, the federation can also engage itself in the judicial process. Ato Kassahun, the President of the Ethiopian Federation of Associations of Persons with Disability, regarding this provision, stated that "the technical Committee has negotiated a lot to come up with this article even though a lot is said against by the representatives of the Employers' Federation."[179]

Art. 11 of the Proclamation provides, with regard to the sanctions available, that "an employer who contravenes the provisions of this Proclamation or regulations or directives issued pursuant to this Proclamation shall be penalized by a fine not less than Birr 2000 or not exceeding Birr 5000 and where the employer fails to rectify the

${ }^{57}$ Art. 2 (9)

${ }^{58}$ Id., Art. 6 (a). 
contravention, within one month, in accordance with the decision of the court, the penalty shall be increased by twofold."

\section{Evaluating the Enforcement of Reasonable Accommodation}

This section is based on the results of the questionnaires administered on 300 visually impaired teachers in Addis Ababa, Hawassa, Soddo and Arba Minch cities. 245 respondents (81.6 percent) were from Addis Ababa while the remaining 55 (18.3 per cent) were from Soddo. 10 respondents (3.3) per cent did not return the questionnaires. The participants who did not return were all from Addis Ababa.

The questions were concerned with the availability of assistive equipments or assistant readers as the case may be, if not available, why, and the solutions for overcoming the barriers. According to Article 6(c) of the Proclamation, employers are required to "assign an assistant to enable a person with disability to perform his work." In this regard, the participants confirmed that no school provides assistants even to correct exam sheets. On the positive front, schools are trying their level best to provide books in braille although their effort, at times, encounters problems.

The majority of the participants in this study pointed out factors such as ignorance of employers, lack of specialized equipments and lack of the skills required to use computers. The responses falling under these three themes made up 58.62 per cent (n equals 170). The most common reason that was raised by 212 respondents $(73.1 \%)$ was the ignorance of employers on the legal regime that requires the assignment of assistants to enable visually impaired teachers perform their tasks efficiently. Admittedly, visually impaired employees share their part in this regard, since they should have informed the employers about the existence the legal regime.

Next to the ignorance of employers, 158 respondents (54.8\%) out of whom 122 respondents were from Addis Ababa, stated that the personal attributes of the visually impaired teachers themselves contributed as reasons for the non-implementation of the assistant-assignment legal regime. Personal attributes may include the fear of the teachers to ask their employers to make available the assistants, and their acts of seeking such assistance from virtuous friends and family members. Next to the ignorance of employers and the personal attributes of the beneficiaries of the scheme, the absence of a legal regime that obliges the government to share the burden of employers on the implementation of the assistant-assignment duty was mentioned as the third major reason for the failure of employers to assign assistants. 100 respondents $(27.9 \%)$ expressed this view. 
In addition to the gap in the enforcement of the assistant-assignment scheme, the response of participants indicated that lack of specialized equipment played its part in the shortage of books in braille. This includes lack of braille reading and writing systems, adaptive computer systems, and screen-reading systems for Windows. 188 respondents $(64.8 \%)$ of the respondents felt that they could not make up for the gap in the provision of books in braille through other assistive technologies due to lack of skills in using computers. All of the respondents from Arba Minch (i.e. 10 respondents) held this view while the percentage of respondents that had this view from Addis Ababa was $62.9 \%$ of the total respondents from the city. The percentage is $66.6 \%$ for Soddo ( 20 out of 30 respondents) and $66.6 \%$ for Hawassa (10 out of 15 respondents).

After having indicated the reasons for the absence of assigned readers and the gap in the provision of materials, the respondents forwarded four suggestions to rectify the problems. The first suggestion shared by the majority of the respondents refers to the need to create awareness on the part of employers through education (233 respondents, i.e. $80.3 \%$ ). The second suggestion stated by 135 respondents $(46.5 \%)$ is the desirability of enacting laws that provide for the need of sharing the burden of accommodating visually impaired employees.

The remaining two suggestions, i.e. provision of training and increase of accessibility through technology, are forwarded as essential schemes to rectify gaps in the provision of books in braille. Computers play a pivotal role in availing soft copy materials, and they can be accessed by JAWS, a screen reading software. Increasing accessibility through technology represents the view of $85.1 \%$ of the respondents (i.e. 247 respondents). However, 214 respondents $(73.7 \%)$ stated that the increase of accessibility to technology should be supplemented by the provision of training to create the required knowledge of operating computers by JAWS. In order to overcome the lack of specialized equipments, 54 respondents $(18.6 \%)$ believe that schools should look for support from non-governmental organizations, and governmental offices.

Two key findings emerge from the data. The ignorance of employers and lack of specialized equipment have posed a challenge for visually impaired teachers. Moreover, the outcome of the questionnaires administered on 300 participants (who assumed the task of teaching in Addis Ababa, Arba Minch, Hawassa and Soddo) demonstrates the absence of assigned readers or some gaps in the availability of books in braille. This explains the failure of employers to implement their obligations, namely, assigning assistants to visually impaired teachers. The respondents stated that it is necessary to 
provide extensive awareness creation programmes for employers about the legal regime that requires the provision of assistants for visually impaired teachers. With regard to the lack of specialized equipment and the gap that exists in the operation of computers, the respondents have suggested the arrangement of training schemes and seeking support from NGOs.

\section{Conclusion}

Ethiopia has defined disability in light of the medical model that portrays disability as a medical problem that seeks a medical solution. This model promotes the establishment of separate venues that serve disabled persons in segregation from their non-disabled peers. The Federal Constitution and the Disability Employment Proclamation of 1994 inclined to the provision of assistance rather than enabling disabled persons. For instance, the Proclamation presupposed the implementation of quota system.

However, Proclamation No. 568/2008 leans to the social model that attributes the blame of disability to the structural and social barriers that impede disabled persons from perfect competition with their non-disabled counterparts. There is disparity between the Federal Constitution and Proclamation No. 568/2008. While the former subsumes disability in the context of the medical model, the latter addresses the issue of disability in the context of the social model. The Proclamation departs from its predecessor, and it requires reasonable accommodation as a mechanism of implementing the right to equal opportunity of disabled workers.

A case in point is the obligation of employers to assign readers. Moreover, they should avail assistive technologies to facilitate the work environment for their employees with visual impairment. The assignment of assistants and the provision of the necessary equipment have a significant role in upgrading the level of participation of visually impaired teachers in the society at large and their professional lives in particular. Moreover, these measures guarantee equal opportunity for visually impaired teachers and can indeed pave the way for stricter evaluation of their performance. 